Article

\title{
Towards Sustainable Development and Preventing Exclusions-Determining Road Accessibility at the Sub-Regional and Local Level in Rural Areas of Poland
}

\author{
Ada Wolny *(i), Marek Ogryzek $[$ and Ryszard Źróbek $(\mathbb{D}$ \\ Institute of Geography and Land Management, Faculty of Geodesy, Geospatial and Civil Engineering, \\ University of Warmia and Mazury in Olsztyn, 10-719 Olsztyn, Poland \\ * Correspondence: ada.wolny@uwm.edu.pl
}

Received: 1 August 2019; Accepted: 2 September 2019; Published: 6 September 2019

\begin{abstract}
The improvement in a regions' accessibility that accounts for various means of inter-regional transport and inter-regional communication is one of the main determinants of sustainable regional development. This study focuses on road accessibility in rural areas where an insufficient number and scope of international and domestic investments can lead to an imbalance in the transport infrastructure. Therefore, the aim of this study was to evaluate road accessibility at the level of the NUTS4 units in view of their sustainable development and their divergence from rural units that are less distant from the main transport routes. The studied area-a province-is situated in the northeast of Poland. Data concerning the travel time, condition, and density of the road network were analysed to develop and compare the measures of road accessibility in individual units and to perform an overall assessment of the NUTS4 units. Partial indices were calculated with the support of the QGIS and ArcGIS software. Peripheral regions in post-socialist countries appear to be particularly underinvested in terms of the transport, including at the local and regional level. The applied methodology supported the presentation of problem peripheral areas that are underinvested and threatened with exclusion.
\end{abstract}

Keywords: accessibility; road network; sustainability; regional development; transport policy; exclusion

\section{Introduction}

The main determinants of regional cohesion and sustainable regional development, including an improvement in a region's accessibility based on various means of transport and inter-regional communication, should be taken into account in regional cohesion and sustainability analyses. A poorly-developed transport network compromises a town's, city's or region's opportunities for dynamic socio-economic growth. In addition, accessibility has become the most important factor in the landscape change, which contributes to urbanisation even in the most remote rural areas when a region gains access to a transportation system [1].

The concept of sustainable development should be defined in detail before attempts are made to determine the way in which transport accessibility is harmonised with sustainable development. The concept was introduced to the literature in the second half of the twentieth century, but it was popularised only in the late 1980s due to increasing interest from politicians and international organisations. Humanity has the ability to make development sustainable by ensuring that it 'meets the needs of the present generations without compromising the ability of the future generations to meet their own needs'. Intergenerational equity is a central element of sustainability [2]. 
Every transport system plays a role in the sustainability of the planet Earth. Sustainable transport is also essential to provide all people with access to the economic and social opportunities necessary for a meaningful life [3]. Therefore, societies living in towns and rural regions strive to develop sustainable transport systems, especially road networks, which will allow them to achieve a sufficient level of economic, social, and environmental growth. However, environmental considerations and natural barriers pose significant challenges in the process of designing transport networks.

Good road accessibility is usually associated with a well-developed network of fast-traffic roads, especially motorways, international transport corridors and an international transport network. The influence that transport capacity and transport improvements have on the economies of societies, whether they have underdeveloped or developed road networks, has long been debated [4].

In this article, road accessibility has been analysed at the micro-level, i.e., closer to local and sub-regional communities of mostly rural regions. Road accessibility is understood to denote ensuring sufficient comfort of travel aimed at satisfying the basic needs of a community by both public (education, healthcare, administration, and culture) and commercial services (use of business facilities, services, craftsmen, etc.). There is more demand for roads to transport people from rural to urban areas. With the increase in the urbanisation process "more roads with high accessibility are required to fulfil daily travel needs" [5].

The aim of this study was to evaluate road accessibility in counties (i.e., level of NUTS4 units) in terms of their sustainable development. Particular attention was paid to the exclusion of peripheral rural regions caused by infrastructural underinvestment-mainly with regard to the construction and repair of roads. The study was conducted in a region situated in Poland because the development of transport systems has been one of Poland's development priorities since its accession to the EU.

The approach to accessibility adopted in the article combines popular measures, such as travel time or distance, with the characteristics and categories of transport routes. The partial indices calculated for the needs of this study may be expressed in different units; therefore, they have been standardised and compared using modern GIS tools. There are no comprehensive systems for analysing entire road networks, whether at the local, regional or national level, which would be helpful for investigating the availability of goods and services and for identifying regions with barriers to sustainable transport development. The results of the study can be used in the decision-making process before further investments are made or the effects of the completed projects are assessed.

\section{Literature Review}

\subsection{Literature Overview}

In the literature, accessibility has been defined as the ease with which goods can reach other destinations, which is measured in terms of the time, cost, seasonality, and type of the provided transport services [6,7]. Investments in transport infrastructure have an effect on core-peripheral relations in geography $[8,9]$.

In view of the different levels and areas of development where accessibility plays an important role, the analysis can begin with regional cohesion in a union of countries, such as the European Union. The relationship between the transport infrastructure and regional cohesion has played a key role in the policies and actions of the European Commission related to the Trans-European Transport Networks (TEN-T, 2005). The main goal of these networks is to serve the entire European continent, while effectively reducing the cost of transport between various geographical and economic regions of the EU [10]. Most authors also emphasised the importance of the concept of accessibility which influences the locational landscape, where investments in the transport infrastructure have been adopted as a tool for improving the outlook of lagging regions. A growing demand for road infrastructure, both new projects and the modernization of the existing infrastructures, has also been observed in many countries [11]. 
Accessibility is an important determinant of sustainable development in provinces, agglomerations, and cities [12-15]. However, this concept has also received recognition from regional and international authorities.

When we take into consideration the "sparseness of regional road networks and the dispersed population in rural or remote regions", it may even be more useful to consider the inverse of accessibility-the remoteness, which is measured by "the difficulty in accessing services and facilities while using the road network" [16].

In the European context, the importance of accessibility has been considerably emphasised and has been adopted institutionally as part of the EU's explicit strategies of regional unification. The EU's policies have generated a demand for research to broaden our understanding of the links between the accessibility and achievement of regional policy goals [10]. In practice, numerous factors have to be taken into account in the infrastructure planning. While many policies and plans focus on optimising traffic, the practical outcomes of such policies could compromise environmental protection measures. The achievement of both goals would require the integration of the two fields. However, "infrastructure policy and planning in particular are strongly sectoral in nature", which contributes to fragmented policy actions. In fact, both policy sectors have developed their own goals that are implemented regardless of the potentially conflicting objectives formulated in other policy sectors [17]. "Although an integrated planning approach to the transportation development has been introduced, this particular approach to the transportation system is viewed in relation to land use and environmental systems, with each of the systems exerting direct and indirect effects on the others. This means that all related aspects of mobility are considered, with conflicts and complementarities among the various policy fields are taken into account" [17].

An efficient and reliable transport system is the backbone of any national or regional economy [18]. Improvements in transport systems undeniably affect development at the regional, sub-regional and even local level. In addition, urban neighbourhoods have a higher population density, road density, transit use, non-motorised transport use, and greater access to local jobs than less urban neighbourhoods [19]. The direct effects of road improvements include "reduced journey time, reduced costs and improved reliability". The resulting benefits will, in particular, be transferred to road users, passengers, and companies. The general expectation is that these effects will deliver "further benefits for the communities" affected by the roads [20].

The applied measures of accessibility focus on one or more components of accessibility, depending on the adopted perspective. Infrastructure-based measures denote the (observed or simulated) performance or service level of the transport infrastructure, such as the 'level of congestion' and the 'average travel speed on the road network' [21]. Such measures are typically used in the transport planning. Measures of road accessibility at various levels constitute a separate issue.

Since this study focuses on local and sub-regional levels, such measures are important for determining accessibility across relatively short distances. The measures that support the determination of road accessibility include the time of travel to the urban core and the time of travel to a county town via different categories of roads [15]. This study relies mainly on the Polish road classification system, which identifies trunk roads, regional roads, county roads, and municipal roads, depending on the entity responsible for managing a given type of road. The "Vehicle velocity in Poland in 2014" report [22] lists the average vehicle speeds on different categories of roads and reveals that vehicle speeds differ by up to $10 \mathrm{~km} / \mathrm{h}$ on various types of roads, in particular in undeveloped areas where the $50 \mathrm{~km} / \mathrm{h}$ speed limit does not apply. Analyses of road accessibility should also account for the density of the road network and the international classification of the road.

In historical traffic data, network impedances are known aa a priori for all departure times, whereas in live traffic, network impedances may change when the vehicle is already on the way; therefore, the "shortest path needs to be recalculated from time to time as new traffic data is acquired" [23]. It should also be noted that the travel time for the private transport is determined by multiple factors, including the weather, unforeseen road incidents (e.g., accidents), and the drivers' personality 
characteristics, and that daily, weekly, and annual fluctuations have also been observed [24]. Different activities may use transport very differently, and hence a given improvement in accessibility may have very different impacts under different circumstances [25]. Analyses that take into account the relationships between the condition of a society and the travel frequency of community members may rely on factors such as low income, limited mobility, young age (non-driving age), old age (over age 62), and ethnic minorities [26].

One of the methods that lead to assessing accessibility is by calculating remoteness-measured by the difficulty in accessing services and facilities while using the road network. This method considers the changes in accessibility/remoteness of different locations in the region under different states for the transport network, e.g., the intact network and a degraded network. This can be done for specified locations and for the entire region. The conceptual models use both an accessibility index (A) and a remoteness index (R) [16]. However, data considering changes in the transport network state are essential to adapt this model. Some of the specific accessibility indices consider the attractiveness of location (city) [13], but it has no effect at the local and sub-regional level, were only one attractive centre has been identified. Finally, one of the most popular standard CBA-approaches makes use of information about how different categories of travellers value reductions of transportation time, waiting, and queuing time, as well as a decrease in the frequency of accidents [27]. Still, this kind of approach is more appropriate when the accessibility is measured within the city borders, where congestion and accidents are more popular problems.

Due to the complexity of road accessibility measures and the multitude of interpretations that affect the topicality of the problem, the condition of the road surface has also been taken into account in the present research. However, it should be noted that this parameter is not assessed consistently or systematically. Yet, taking data availability and research area into consideration an original set of indices has been used in this study.

In countries where transport services are not well developed, are being introduced or are not widely used, the relevant services are planned mostly with the use of ad hoc procedures. Ad hoc methods are commonly applied if the data necessary for "sophisticated planning are not readily available or are inaccurate" [28]. This problem is encountered by the Polish researchers on a daily basis. Optional and unobvious accessibility indicators should be developed to address the issue.

\subsection{Research Approach and Objectives}

The analysis of the literature indicates that analyses and assessments of road accessibility as a determinant of sustainable development are still important. Their importance is evident in Central and Eastern European countries where the infrastructure development has been a priority since the political transformations of the 1990s and the enlargement of the European Union, and where the infrastructure development is one of the main stimulants of socioeconomic growth. Those countries have implemented numerous road infrastructure projects, with major investments in express road networks. The aim of these measures was to attract foreign investors, tourists as well as important cultural and sporting events. This was certainly the case in Poland, especially between 2004 and 2015, and the infrastructure development would not have been possible without subsidies from dedicated programmes, especially those financed by the EU. The undertaken projects have improved accessibility, mainly in the largest Polish cities and urban areas, which were the main beneficiaries (ring-roads, motorways, and express roads). This study analyses areas with fewer and less extensive international and domestic investments in road development. These areas were discussed not only in terms of interregional connections, but also at the local level, including journeys that are made every day or several times a week. The location-based accessibility model considers the core components of accessibility (people, transport, and activity locations) [29]. At the sub-regional level these activities are usually located in the nearest town within the same county. It was assumed that residents of rural, municipal, and rural-municipal areas travel frequently (commute daily to work), or with an average frequency (to visit a doctor, specialist, service provider, office or to shop), or rarely (to a cultural or 
sporting event). People attending cultural or sporting events are prepared to travel long distances, including on a regional scale (between counties), but these types of journeys are not covered by the study, which focuses on trips that are made frequently or with average frequency.

However, researchers investigating frequent trips are burdened with the lack of data or incomparability of data relating to the different categories of routes. In Poland, only the primary roads are classified based on their technical condition. The reports on changes in the road condition, published by the General Directorate for National Roads and Motorways (GDfNRM) in 2004 and 2015 [30], have different descriptions of four road condition scores (A, B, C, and D, where D is the worst condition). Scores A (good condition) and B (acceptable condition) have a common description. However, the above scores are not applied to assess the condition of secondary and tertiary roads, which are often used for daily and weekly trips. In particular, the county-level roads play a major role in the spatial distribution of rural settlements and create the transportation network system constructed to strengthen the spatial connections between the townships [31]. Unfortunately, the county-level roads condition can be only assessed based on the fact that they have been recently repaired or by field studies.

Despite the fact that the travel time appears to be the most widely used measure of accessibility, the condition of the road surface is an equally important consideration. However, this parameter can combine different partial indices where data are insufficient or unreliable.

The aim of this study was to evaluate road accessibility in counties (i.e., level of NUTS4 units) in view of their sustainable development and their divergence from units that are less distant from the main transport routes. The reliability of the relevant data varies considerably. Particular attention was paid to the exclusion of peripheral regions caused by infrastructural underinvestment-mainly the construction and repair of roads.

The specific goals of the study were to:

- determine transport accessibility in selected sub-regions in relation to the completed road investments;

- determine the impact of EU subsidies on the modernisation and construction of regional roads for local use;

- identify threats to regional cohesion resulting from the isolation of areas situated far from the main roads.

This study attempts to answer the following key questions: Are peripheries doomed to infrastructure underinvestment? How can historical and political factors affect travel comfort? Are areas of great natural value and areas attractive to tourists best protected by giving up infrastructure investments?

\section{Materials and Methods}

\subsection{Area of Research}

The area being analysed lies within the province of Warmia and Mazury. It is a region in the north-east of Poland, whose northern border forms the EU-Russia border (Figure 1). Since this area was incorporated into Poland after World War II, the development of settlements and transport connections has been affected by historical factors (solutions and a network developed earlier in Eastern Prussia, the settlement of repatriates and incoming population, mainly from the central and eastern part of the country, in former Prussian towns and villages), as well as the great natural value (with numerous lakes, rivers, forests, and protected landscape areas). The province of Warmia and Mazury has 1.44 million inhabitants and it covers an area of $24,173.47 \mathrm{~km}^{2}$. The average population density is among the lowest in the country and is 60 people $/ \mathrm{km}^{2}$ [32].

Basic data on the population status and migrations are included in Table 1. Population characteristics include the population density—number of people per $\mathrm{km}^{2}$, change in the number of 
citizens (per 1000 people) - the rise or loss in the number of population year to year and differences in the population caused by migration-difference between the number of persons having entered the territory and the number of persons having left the territory in the course of the year.

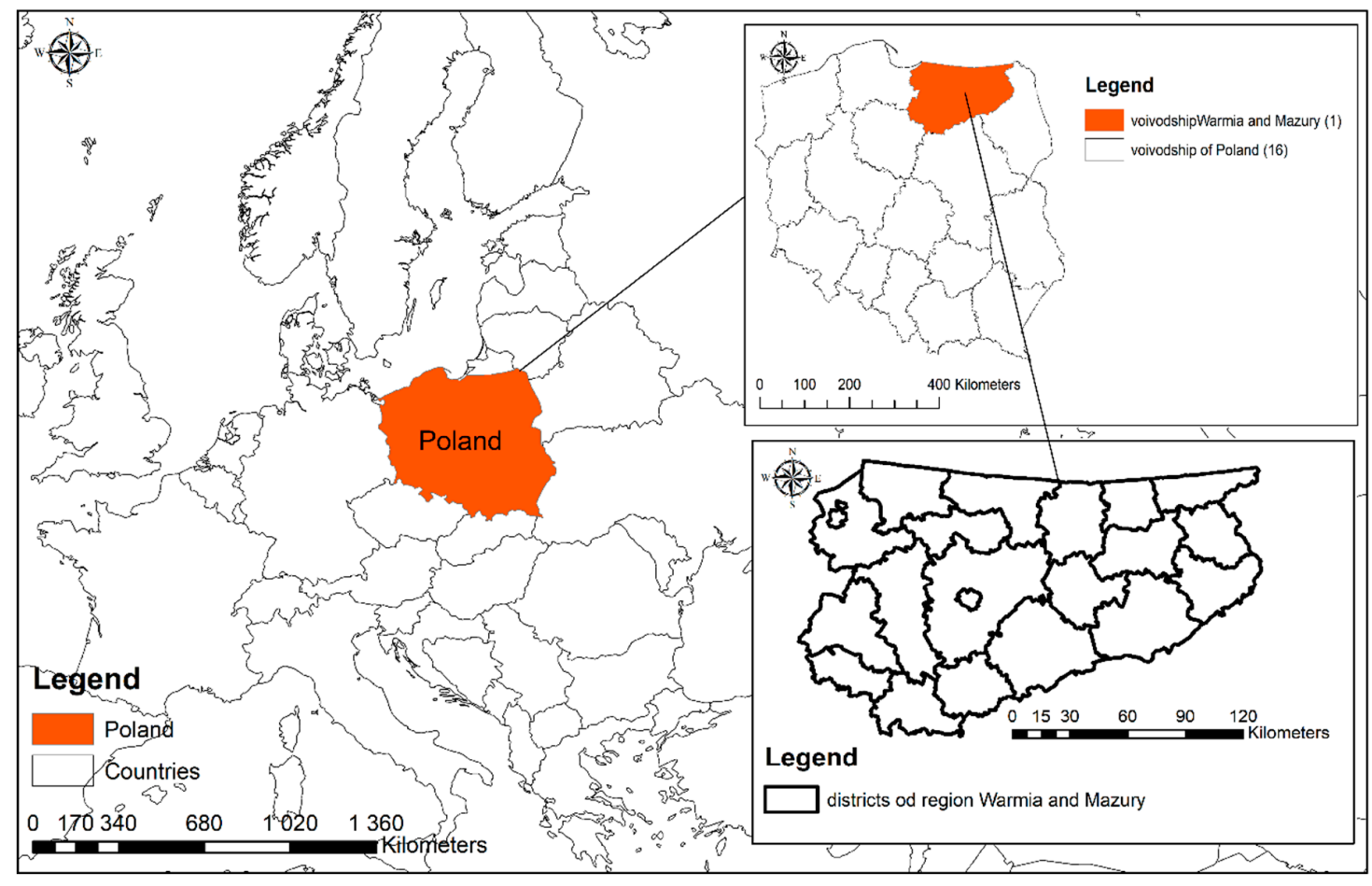

Figure 1. The area of research location.

Table 1. Characteristics on the population in the counties making up Warmia and Mazury.

\begin{tabular}{|c|c|c|c|c|}
\hline \multirow{4}{*}{ County } & \multicolumn{4}{|c|}{ Population Characteristics } \\
\hline & $\begin{array}{l}\text { Population } \\
\text { Density }\end{array}$ & $\begin{array}{l}\text { Change in the Number of } \\
\text { Citizens (Per } 1000 \text { People) }\end{array}$ & $\begin{array}{c}\text { Balance of } \\
\text { Internal Migration }\end{array}$ & $\begin{array}{c}\text { Balance of Foreign } \\
\text { Migration }\end{array}$ \\
\hline & 2016 & 2016 & 2016 & 2016 \\
\hline & People $/ \mathrm{km}^{2}$ & Number of People & Number of People & Number of People \\
\hline Bartoszyce & 45 & -8.3 & -352 & -18 \\
\hline Braniewo & 35 & -6.0 & -248 & 2 \\
\hline Działdowski & 69 & -1.5 & -210 & 2 \\
\hline Elblag & 41 & -2.2 & -123 & -29 \\
\hline Ełk & 81 & 5.6 & 206 & 30 \\
\hline Giżycko & 51 & -2.5 & -120 & 18 \\
\hline Iława & 67 & 0.0 & -124 & 11 \\
\hline Kętrzyn & 53 & -7.5 & -345 & -1 \\
\hline Lidzbark & 45 & -5.4 & -131 & -8 \\
\hline Mragowo & 47 & -3.7 & -102 & -29 \\
\hline Nidzica & 35 & -6.7 & -185 & 2 \\
\hline Nowe Miasto & 64 & -3.5 & -234 & 7 \\
\hline Olecko & 40 & -3.9 & -75 & -4 \\
\hline Olsztyn & 44 & 5.9 & 584 & -40 \\
\hline Ostróda & 60 & -3.9 & -314 & -156 \\
\hline Pisz & 32 & -4.8 & -306 & -10 \\
\hline Szczytno & 36 & -1.5 & -164 & -48 \\
\hline Gołdap & 35 & -4.7 & -159 & 1 \\
\hline Węgorzewo & 34 & -7.4 & -146 & 3 \\
\hline the city of Elblag & 1.518 & -3.7 & -180 & -14 \\
\hline the city of Olsztyn & 1.958 & -2.6 & 25 & 10 \\
\hline
\end{tabular}

Source: Own study using data from the Central Statistical Office in Poland. 
A simple comparison of the data collected in Table 1 leads to the conclusion that only the county of Ełk has a population density rate above average, significant population growth, and positive balances. Despite their high density, Olsztyn and Elblagg are losing their citizens. Unfavourable migration and depopulation trends can be seen in the Pisz and Bartoszyce county (low values of balance of internal and foreign migration). Most counties (outside of major cities) are sparsely populated, 13 out of 21 counties have a population density below the Polish average. In addition, current migration trends have caused a decrease in their population, only the Ełk and Olsztyn counties have gained significantly (most of the values of 'change in the number of citizens per 1000 people' are negative).

The province of Warmia and Mazury comprises 21 NUTS4 units-19 counties and two cities; the latter include Olsztyn - the capital of the region-and Elblag, which has the second largest population (Table 1). Due to the fact that the borders of these two cities coincide with the borders of highly urbanised areas with a dense transport network, they were excluded from the research conducted for this study.

The choice of the study area was affected by both the features of the region and its proximity-it is an area close to us because this is where we work and live, and because we can conduct extensive and specific studies in the selected location. In addition, it should be mentioned that the road accessibility of the province has been analysed, though the analyses focused mainly on the intensity of traffic on various roads, the length of roads of various categories and their condition [33], and the identification of districts with a favourable position along the main trunk roads. Unfortunately, it is one of these regions that has "the limited visibility and lobbying power to place infrastructural and transport connectivity on the national political and policy agenda" [34]. The transport system in the province is shown on the map used in the Land Use Plan for the province of Warmia and Mazury (Figure 2).

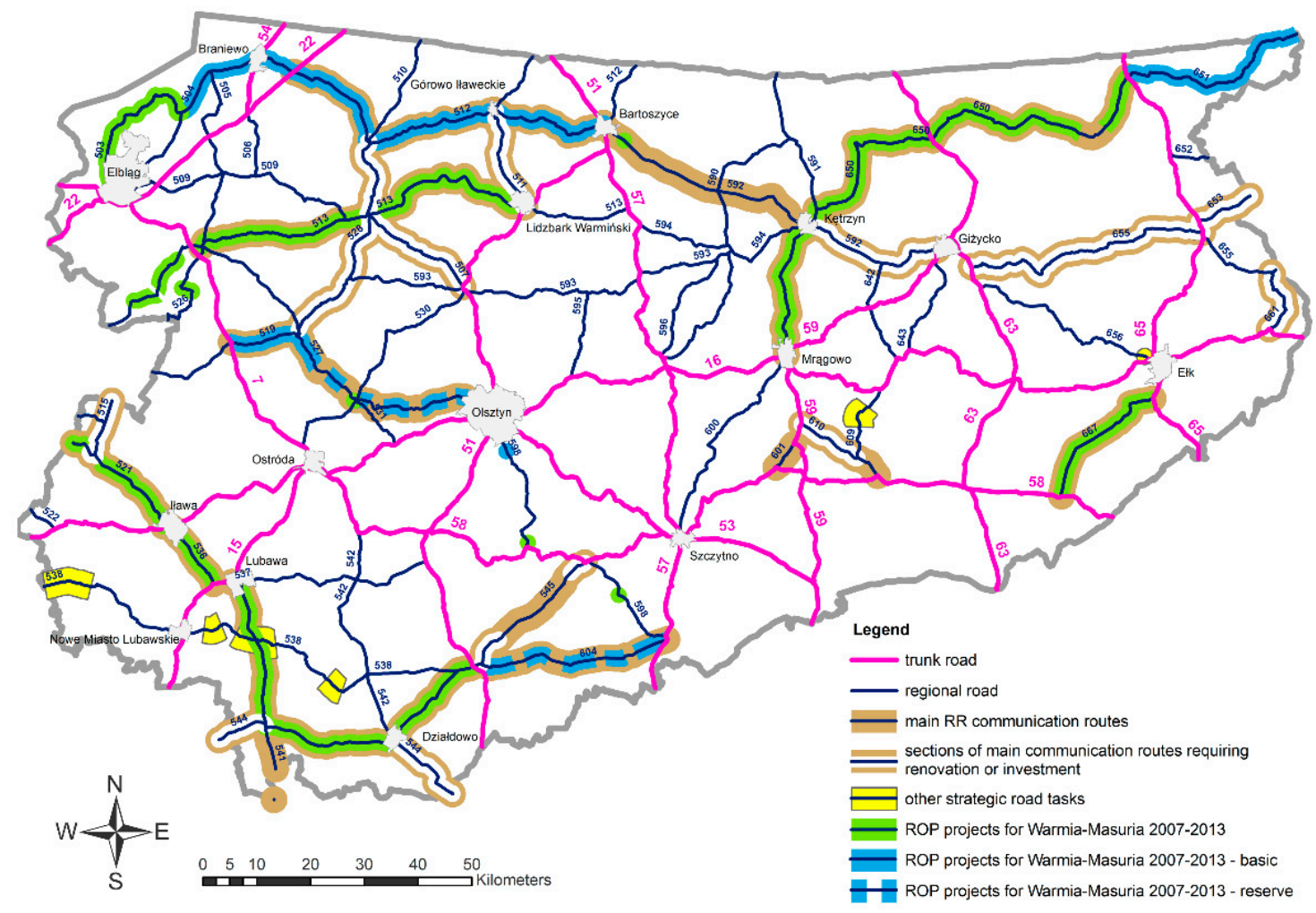

Figure 2. The transport system in the province. Source: Own study with a use of data from [35].

In view of the main goals of this study, the procedure of analysing road accessibility was conducted in several stages:

Stage 1 - selection of factors that affect road accessibility in the evaluated units based on a review of the literature and statistical analyses; 
Stage 2 - selection of the area for analyses with regard to the aim of the study;

Stage 3 -acquisition of data from the available sources, including the Central Statistical Office (CSO), other statistical reports, OpenStreetMap, General Directorate for National Roads and Motorways (GDfNRM), Head Office of Geodesy and Cartography (HOGC), Road Authority of the Region of Warmia and Mazury (WMRA), Regional Operational Programmes (ROP);

Stage 4 -development of methods for calculating partial indices for accessibility assessments based on selected data and the adopted parameters;

Stage 5 -integration of data in the GIS software and presentation of maps;

Stage 6 -accessibility assessments in various counties based on the analyses of pooled data in the GIS software;

Stage 7 -interpretation of the results.

\subsection{Main Indicators of Road Accessibility in Selected Districts (Counties) and Calculation Methods}

The indicators of road accessibility were determined and compared in individual units to perform an overall assessment of the selected countries. Due to the lack of consistent and complete data, the study focused on the travel time, the condition, and density of the road network. For this purpose, source data were transformed into six partial indices, which were then used to create the final (summary) index. The partial indices were calculated with the support of the QGIS software, and the accumulated data were visualised in the ArcMap component of the ArcGIS software. The calculation method for each indicator is described below:

I1-mean time of travel to a county town (in minutes) from the most distant points in the county

$$
\mathrm{I} 1=\sum_{i=1}^{N} t_{i} / N
$$

where:

$\mathrm{N}$-number of directions in which the road graph (for an optimal road) was calculated

$t_{i}$-travel time in a chosen direction * (minutes) - recalculated from hours (h)

* based on the average speed in the analysed section of the road $(\mathrm{km} / \mathrm{h})$ and the length of the analysed section $(\mathrm{km})$ (sections were analysed separately for every road class)

Travel time has been one of the most popular measures of accessibility since this issue became the subject of diverse research in land use planning [36,37], social studies and health care [38,39], and studies investigating the consequences of transport development [14,40].

In this study, the following specific conditions were taken into account when measuring travel time:

- the distance from a county town was measured to the northernmost, southernmost, easternmost, and westernmost points in that county,

- counties are Polish administrative units that were created as a result of the 1999 public administration reform with the aim of decentralisation; counties have designated areas and borders,

- the average driving speed on trunk, county, and regional roads, and their proportion in the total length of the journey in a given direction, assuming that the mean vehicle speed (in the built-up and non-built-up areas) was set at: Seventy $\mathrm{km} / \mathrm{h}$-on trunk and regional roads, $60 \mathrm{~km} / \mathrm{h}$-on county roads, $80 \mathrm{~km} / \mathrm{h}$ - on partially one-lane and partially two-lane trunk roads (expressways where the maximum speed is increased from $90 \mathrm{~km} / \mathrm{h}$ to $120 \mathrm{~km} / \mathrm{h}$ ); the mean vehicle speeds were based on the national report [22],

- the data on the existing road network were acquired from the OpenStreetMap portal and supplemented with the data published by the GDfNRM and the WMRA,

- the methods for calculating the route and travel time were specified for the 'road graph' function ('optimal road'), which accounts for changes in the road category, where 'road graph' calculates 
the shortest path between the two points, and plots this path over the road network (taking into consideration a certain road category), and uses the definition of optimisation criterion.

I2-density of the main road network in a county, i.e., the length of primary, secondary and tertiary roads per $\mathrm{km}^{2}$.

$$
\mathrm{I} 2=\left(l_{n r}+l_{p r}+l_{d r}\right) / A_{C}
$$

where:

$l_{p r}$-length of regional (secondary) roads in a particular county $(\mathrm{km})$

$l_{n r}$-length of national (primary) roads in a particular county $(\mathrm{km})$

$l_{d r}$-length of district (tertiary) roads in a particular county $(\mathrm{km})$

$A_{C}$-area of a particular district $\left(\mathrm{km}^{2}\right)$

The density of the road network was calculated based on:

- the data on the existing road network acquired from the OpenStreetMap portal and supplemented with the data published by the GDfNRM and the WMRA,

- the rules applicable to the "line length in a polygon" function in the GIS software (Sum line lengths tool (QGIS) - summarises each input polygon vector layer feature by the length of the input line vector layer. As some of the roads are in more than one district, the tool "cuts" them at the point when they are crossing with polygon boundaries).

- division of the length of roads of various categories by the area of polygons (i.e., counties) and the sum of individual partial indices.

\section{I3-the length of roads under construction or under repair in a county $(\mathbf{k m})$.}

The construction and exploitation of artery roads seems an adequate policy and accessibility measure as it favours the creation of new infrastructures [41]. Road repairs may increase the travel time, decrease travel comfort, cause route narrowing, and detours. However, they are necessary for road improvements. The analysis was based on a selection of roads with the "under construction" status, and the line length was calculated within a polygon with the "line length in a polygon" function, which summarises each input polygon vector layer feature by the length of the input line vector layer and "cuts" these lines at the point when they are crossing with polygon boundaries. The data were acquired mainly from the OpenStreetMap service and the GDfNRM.

$$
\mathrm{I} 3=l_{c r}-l_{i m r}
$$

where:

$l_{c r}$-length of roads under construction $(\mathrm{km})$

$l_{\text {imr }}$-length of modernised roads $(\mathrm{km})$

The following factors were taken into account in the calculation process:

- The length of roads that would be transformed from one-lane to two-lane trunk roads; these roads are partially two-lane roads with reduced speed sections,

- the length of "temporary" roads that will not be included in the future road network,

- the general classification of roads (where the roads under construction will be future speedways or primary/national roads),

- partial traffic obstruction of varied duration caused by the long-term construction process.

I4-proportion of the length of regional roads whose repair was subsidised by the EU in the total length of regional roads (within a county)

$$
\mathrm{I} 4=l_{m p r} / l_{p r}
$$


where:

$l_{m p r}$ - length of modernised regional (secondary) roads in a district $(\mathrm{km})$ (which the repair was subsidised by the EU funds-with a use of data published by WMRA)

$l_{p r}$-length of regional (secondary) roads in a district $(\mathrm{km})$

Secondary roads have not been assigned categories, which is why their condition is assessed based on the road upgrade plan, where modernised roads are characterised by high-quality surfaces and suitable conditions for developing medium speeds. In terms of the transportation policy, it can be seen that investments aimed at reducing congestion, travel time, also tend to increase reliability, resulting in the reduction of transportation costs [42].

That is why the relevant calculations were based on the data acquired from the Regional Road Authority as part of the schedule for road upgrade projects subsidised by the EU in the 2007-2013 perspective. The scale of repairs subsidised by the EU, based on their location, is shown in Figure 1.

I5-increase/decrease in the length of county roads with an improved surface (other than bitumen or concrete).

The length of county roads with an improved surface was compared between 2007 and 2014 based on the regional statistical data published by the Regional Statistical Office (for counties in the Region of Warmia and Mazury). This alternative measure indicates the actual possibility of reaching average speeds by analysing the improvements in the surface of tertiary roads.

$$
\mathrm{I} 5=l_{i d r 2014}-l_{i d r 2007}
$$

where:

$l_{\text {idr2014 }}$-length of district (tertiary) roads with improved surface in $2014(\mathrm{~km})$

$l_{i d r 2007}$-length of district (tertiary) roads with improved surface in $2007(\mathrm{~km})$

I6-proportion of the length of trunk roads whose repair was subsidised by the EU in the total length of trunk roads

$$
\mathrm{I} 6=l_{m n r} / l_{n r}
$$

where:

$l_{m n r}$-length of modernised national (primary) roads in a particular district $(\mathrm{km})$ (which the repair was subsidised by the EU funds-with a use of data published by GDfNRM)

$l_{n r}$-length of national (primary) roads in a particular district $(\mathrm{km})$

The calculations were based on data from a progress report on the implementation of the Infrastructure and Environment Operational Programme (POIS.06) in the 2007-2013 perspective in the Region of Warmia and Mazury. The length of modernised national roads denotes the length of roads that have been transformed from one-lane to two-lane trunk roads with a maximum speed raised to $120 \mathrm{~km} / \mathrm{h}$ and significantly reduced travel times between the towns.

$\mathrm{I}_{\mathrm{F}}$-final index

$$
\mathrm{I}_{\mathrm{F}}=\sum_{i=1}^{N} I_{i} / P D * 100
$$

where:

$I_{i}$ - the sum of partial indices that were unified and standardised with the use of the GIS tools $P D$-population density specified in Table 1.

In the calculation of the final index, the population density was used as a weight for the predicted 'request' for accessibility, where the daily congestion would be also reduced in less populated counties. 
Simple statistical methods, including the average and the weighted average, as well as the spatial analysis functions in the GIS software were used in the study.

Due to differences in the form, the indices were analysed separately, and each index was divided into five equal classes. Vector data were replaced with a raster data with the Feature To Raster tool (with cell size 10). This tool converts features to a raster dataset. Any feature class (geodatabase, shapefile, or coverage) containing point, line, or polygon features can be converted to a raster dataset. This tool always uses the cell centre to decide the value of a raster pixel.

Then the 'Raster Calculator' (ArcGIS) was used. This tool builds and executes a single Map Algebra expression using the Python syntax in a calculator-like interface. The Raster Calculator tool generally follows the standard connectivity behaviour of models in the Model Builder, with some exceptions resulting from the requirements to formulate a valid Map Algebra expression.

The tool supports simple algebraic operations (addition, subtraction, multiplication, division), complex functions (exponential, logarithmic, trigonometric, etc.) as well as the development of algebraic and logical operations by overlapping several maps (typical operations: Addition, subtraction, multiplication, division, normalized ratio, alternative, conjunction, etc.) to obtain a results map. If data are visualised, a decision can be made on how to classify and define the ranges and classification for the classes. A larger amount of data enables a larger number of classes to be used. The method of defining the ranges and borders of classes (the highest and the lowest values in each class) determines the classification of an object into a class and the appearance of the thematic layer. The general aim is to guarantee that objects with similar values are placed within the same class [43].

The reclassification process was necessary to unify the indices: The Reclassify tool was used, and all six indices were divided into five new classes (where five and the black colour denote the highest value, and one and the white colour denote the lowest value).

In order to sum up the rasters' values, the Spatial Analyst tools were needed. They are accessed through an algebraic format-an object whose name is identified to the left of an equal sign is created based on a tool or operator stated to the right of the equal sign. Even more complexity can be incorporated by adding logic and combining multiple process models with the Map Algebra or ModelBuilder. One of the most basic Spatial Analyst operations is the addition of two rasters (Figure 3).

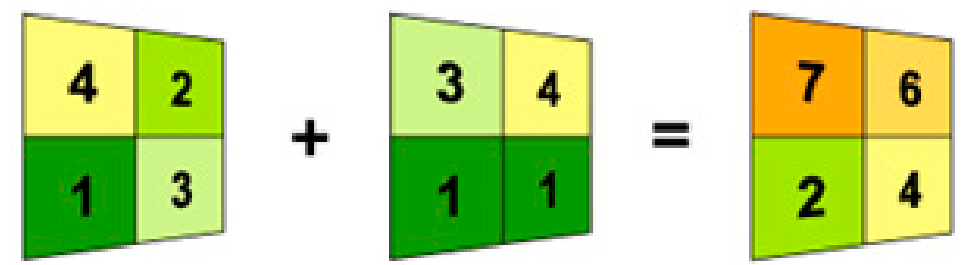

Figure 3. Summing the values of the rasters with a use of the Spatial Analyst tool. Source: [43,44].

The final indicator is created by summing up the results from the previous rasters (for indicators from one to six) one by one to generate the final matrix. The final indicator is divided by the population density and expressed in percentage terms to determine the transport accessibility in the selected sub-regions. The method supports the analyses and comparisons of different indicators without developing a complex model.

\section{Results}

In the first stage, individual partial indexes were calculated for selected counties, taking the average speed on the section of the road $(\mathrm{km} / \mathrm{h})$ and the length of the section $(\mathrm{km})$ into consideration (sections were separated according to the road classification). The journey time measurement took into account the distance from the county town to the northernmost, southernmost, easternmost, and westernmost points. The journey time was measured using a 'road graph', with the speed on each stretch of the route indicated by the use of the GIS software, assuming that the mean vehicle speed 
is: Seventy $\mathrm{km} / \mathrm{h}$-on trunk and regional roads, $60 \mathrm{~km} / \mathrm{h}$-on county roads, $80 \mathrm{~km} / \mathrm{h}$-on partially one-lane and partially two-lane trunk roads (an expressway on which the maximum speed is increased from $90 \mathrm{~km} / \mathrm{h}$ to $120 \mathrm{~km} / \mathrm{h}$ ). Still, there were no routes covered only by expressways and the portion of the county, regional, and one-lane trunk road varied due to differences in the road system of each county. The average time of a journey is an index calculated in minutes (rather than hours).

Subsequently, the index data were marked on a map of the province of Warmia and Mazury. Further, the distribution of values for partial indexes was determined, taking into account the values calculated for individual units. The results are presented on maps. The scale of assessment was unified by classifying the values into five intervals, from one to five, where five means the best, desired values and one means the poorest results.

The I1 index, i.e., the average time of a journey to a county town, in minutes (taking into account the extreme points) ranged between 17 and $40 \mathrm{~min}$. The shortest time was calculated for the county of Nidzica and the longest was for the county of Ostróda. However, this means that the average journey time is the shortest for the county of Nidzica, and it needs improvement in the county of Ostróda. It is significant that the county is elongated longitudinally, which increases the journey time from the southern and the northern ends of the county. Overall, apart from the county of Nidzica, four counties were in the highest range of classification, with journey times of between 17 and $22 \mathrm{~min}$ (Figure 4).

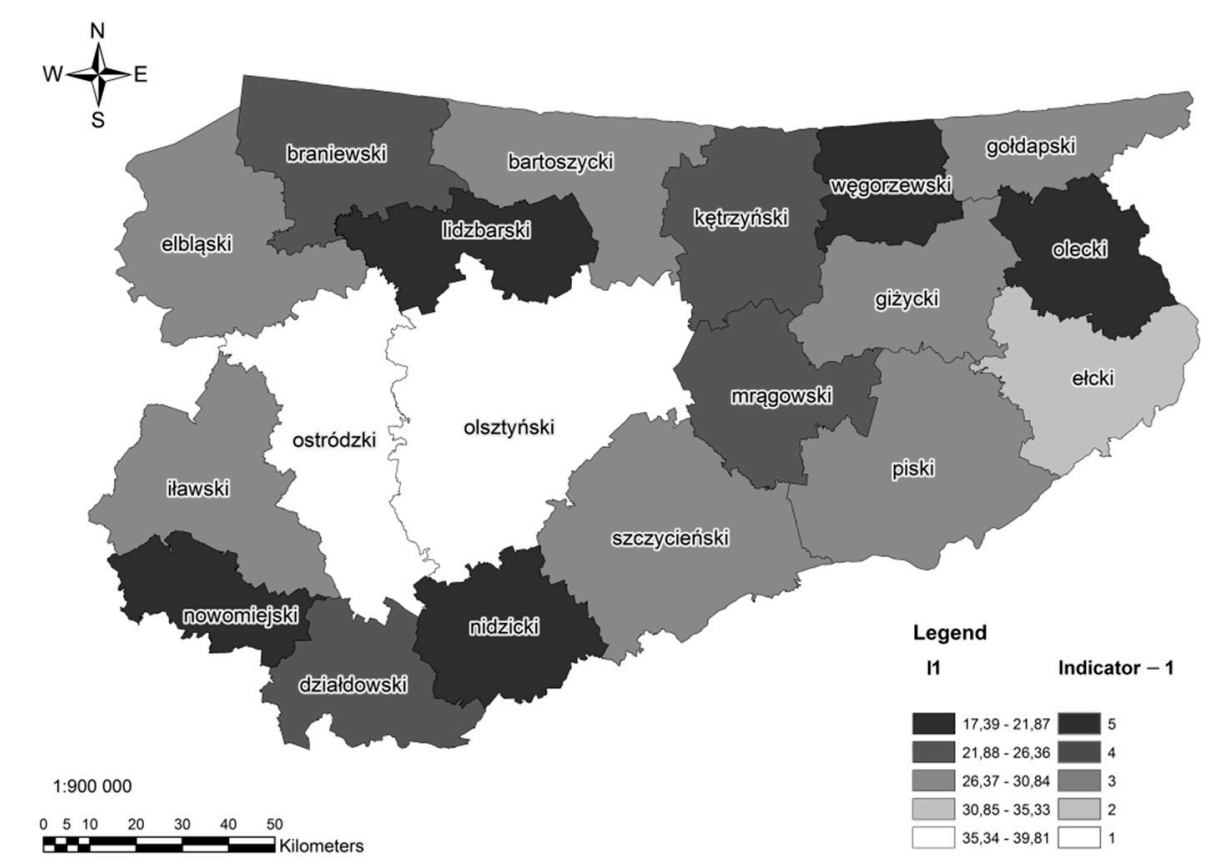

Figure 4. Mean time of a journey to a county town (in minutes) from the most distant points in county. Source: Own study.

Within their administrative borders some of the NUTS4 units are more elongated (and the routes to the northernmost or southernmost locations in a certain county might be much further than the easternmost and westernmost points. However, the I1 values not only depend on the county's shape, but also on a county town's location within a county borders, as well as the road category (and average speed associated with this category).

The I2 index-the density of the main roads in a county, i.e., the length of trunk roads, regional roads, and county roads per $1 \mathrm{~km}^{2}$ lay within the range from 0.11 (in the county of Gołdap) to 0.45 (in the county of Nowe Miasto). Class 5 also included the county of Działdowo. Considerably lower values of the indexes were calculated for the northern part of the province, close to the border, where the density of trunk, regional, and county roads (despite the diverse area of the counties) is unsatisfactory. 
The situation is the worst in the county of Gołdap (Figure 5). The road density is low in only one of the counties in the south of the province (Pisz).

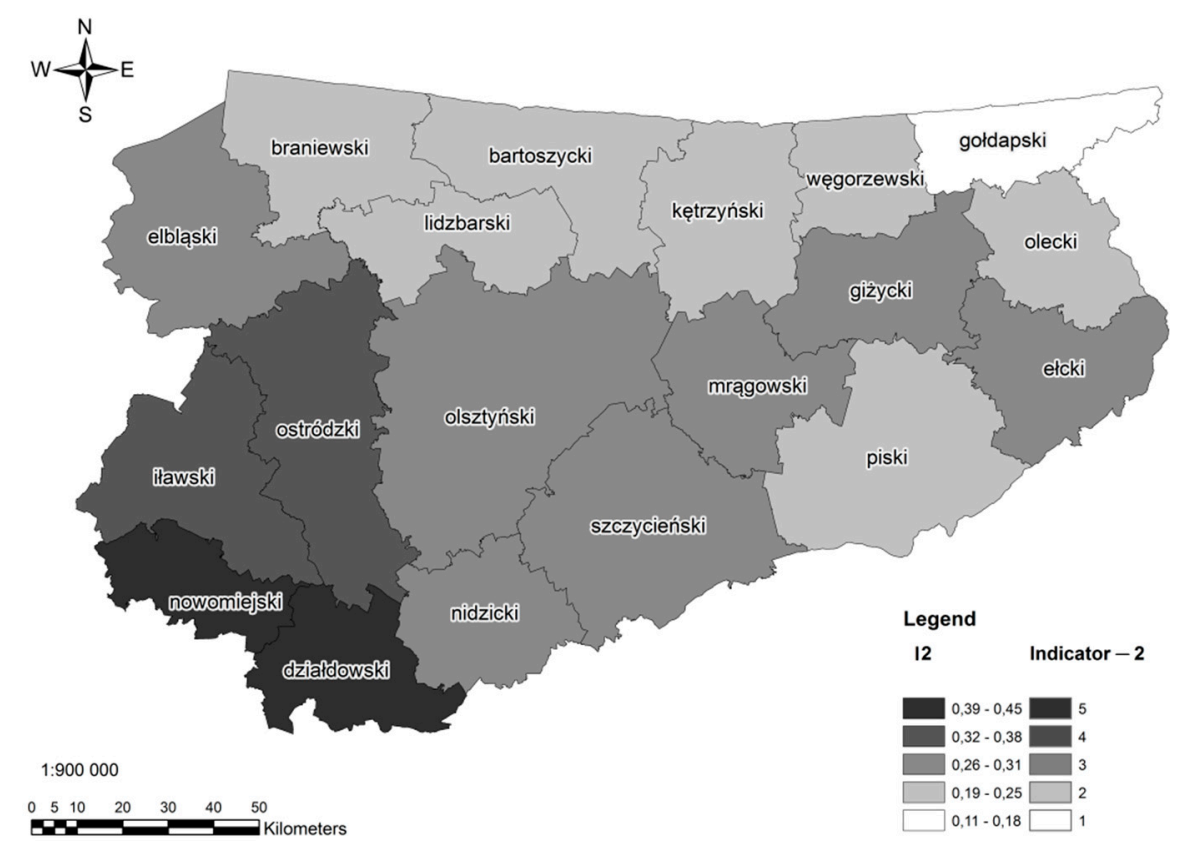

Figure 5. Density of the main road network in a county, i.e., the length of the road (primary, secondary, and tertiary) per $\mathrm{km}^{2}$. Source: Own study.

It should be emphasised that the results do not depend on a size of counties. The largest counties like Olsztyn receive a similar result as more than two times smaller Ełk or Mragowo and results for smaller counties like Nowe Miasto Lubawskie, Gołdap, and Lidzbark Warmiński differ a lot (Figure 5).

Another partial index- $\mathrm{I} 3$ - the length of roads under construction or under repair (in $\mathrm{km}$ ) refers mainly to the roads being expanded and modernised, including the construction of two-lane trunk roads. As the transport modernization in Poland is identified as a long term and multistage proccess it was found worth considering. The index ranges from $0.00 \mathrm{~km}$ (for nine counties in the province) up to $179.21 \mathrm{~km}$ (in the county of Olsztyn); however, it must be stressed that over $99 \%$ of the total length of roads under construction or under repair in the province are situated in four counties-Elblag, Nidzica, Ostróda, and Olsztyn (Figure 6). It is in these counties that the fast-traffic S7 road and the modernised trunk roads number 16 and 51 are being constructed. After the projects are completed, the comfort of the journey will be much higher than now, and since the work is close to completion, a higher length of roads under construction and modernisation will be better for the county.

Another index (I4) refers to the effect that EU subsidies had on improvements to the road condition in the province. Regional roads, which condition was improved with a use of EU subsidies, are visualised on Figure 2 (marked in green and blue). These regional roads are localised in 11 out of 20 counties in the province. The proportion of the length of regional roads whose repair was subsidised by the EU in the total length of regional roads (within a county) ranged from the lowest of 0.00 (in seven counties) to the highest of 0.91 (in the county of Wegorzewo). It was also high in the county of Gołdap, but since this is also a result of a low density of trunk roads in this county, the modernisation of even such a relatively short section was significant (Figure 7). 


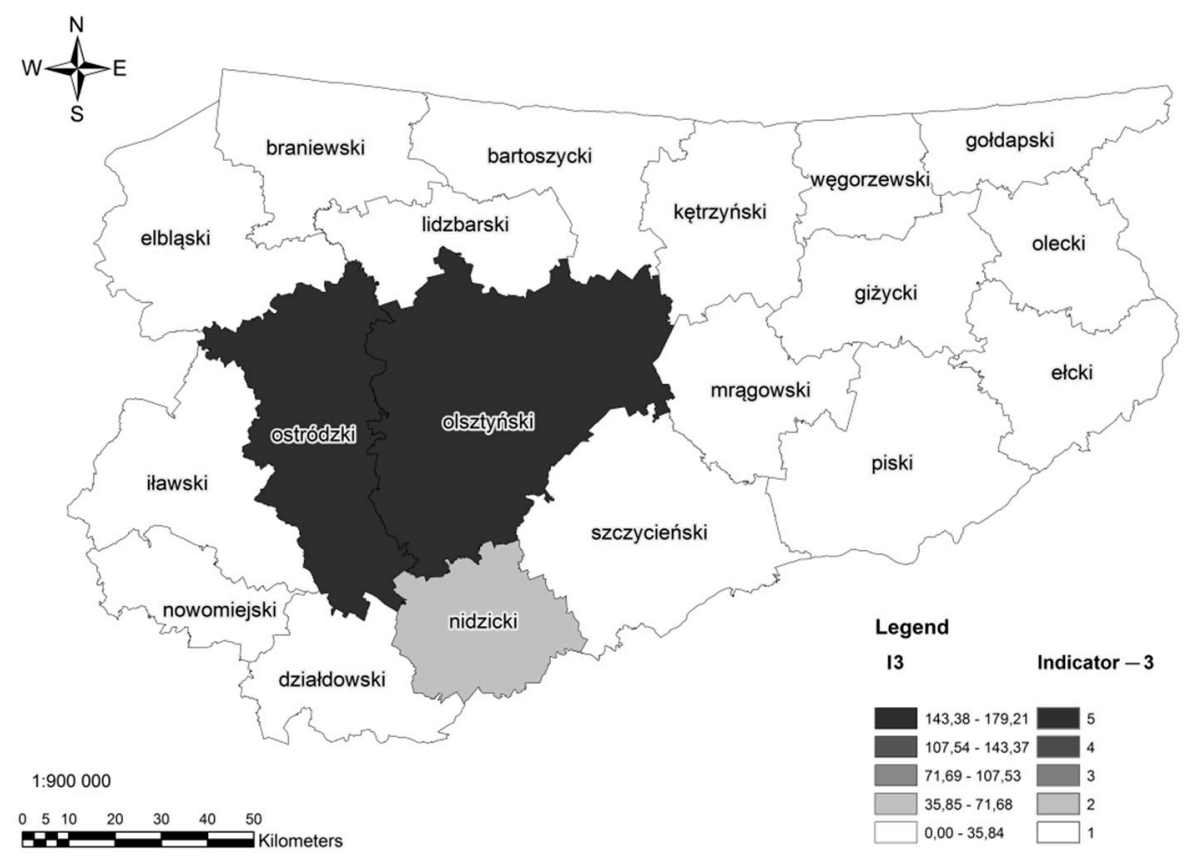

Figure 6. The length of roads under construction or under repair in a county $(\mathrm{km})$. Source: Own study.

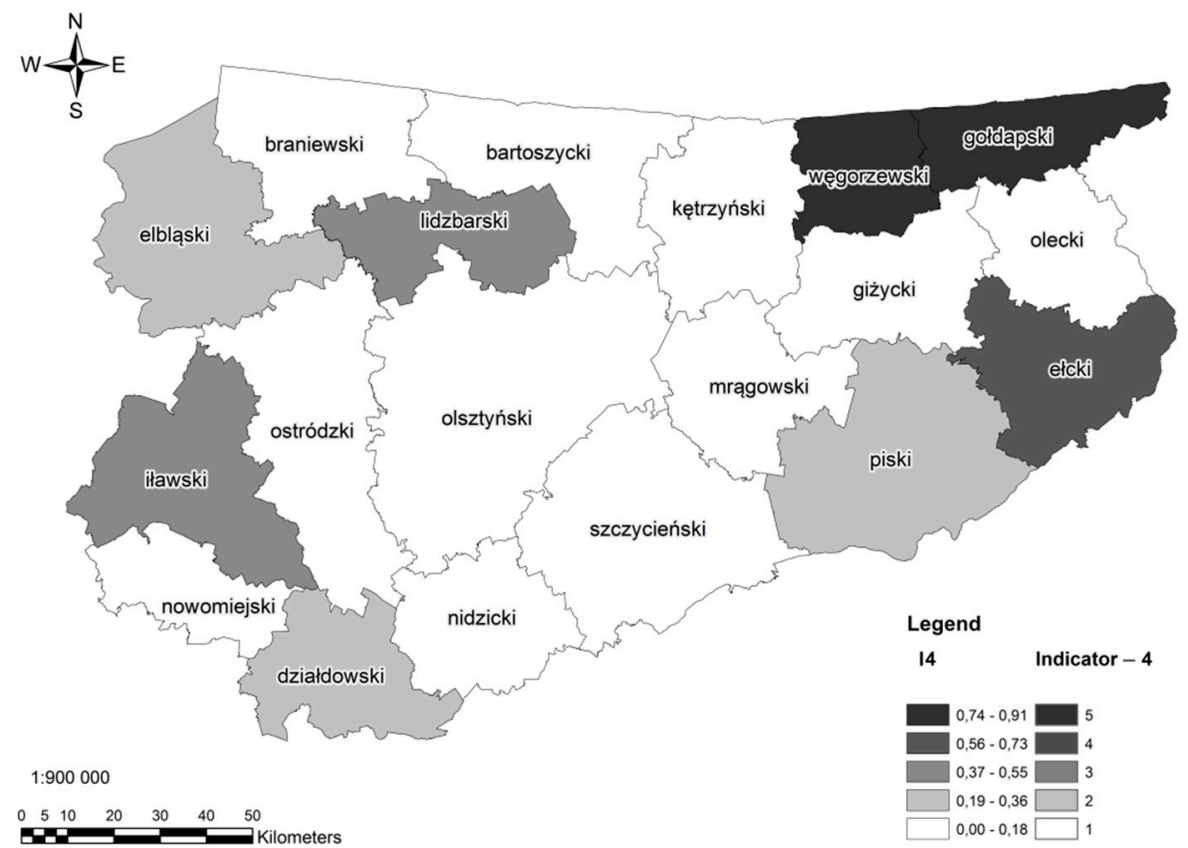

Figure 7. The portion of the length of regional roads whose repair was subsidised by the EU in the total length of regional roads (within a county). Source: Own study.

It should be emphasised that before the repair programme subsidised by the EU most of the regional roads, which are quite narrow and tortuous, were also in poor condition. While most of the routes are modernised and repaired, the travel time reduces and the average speed and safety is likely to rise.

The 15 index is an increase or a decrease in the length of county roads with an improved surface (i.e., better than a dirt road and worse than a bitumen road). The index lay within a broad range, from -66.9 (the county of Olsztyn) to 37.6 (the county of Pisz). Except for the county of Pisz, high values of the I5 index were noted also for the counties of Szczytno, Olecko, and Iława in the eastern 
and southern part of the province. On the other hand, the decrease in the length of county roads with an improved surface was reported in most of the northern and central counties.

An increase in the length of county roads is not a bad thing, but in this case, it results in travelling on worse, less durable surfaces, which translates into lower comfort of travel. For trunk or regional roads, an improved surface is not permanent, and it can be used temporarily (e.g., during expansion or repair work). Hence, the analyses were restricted to third-class roads (Figure 8).

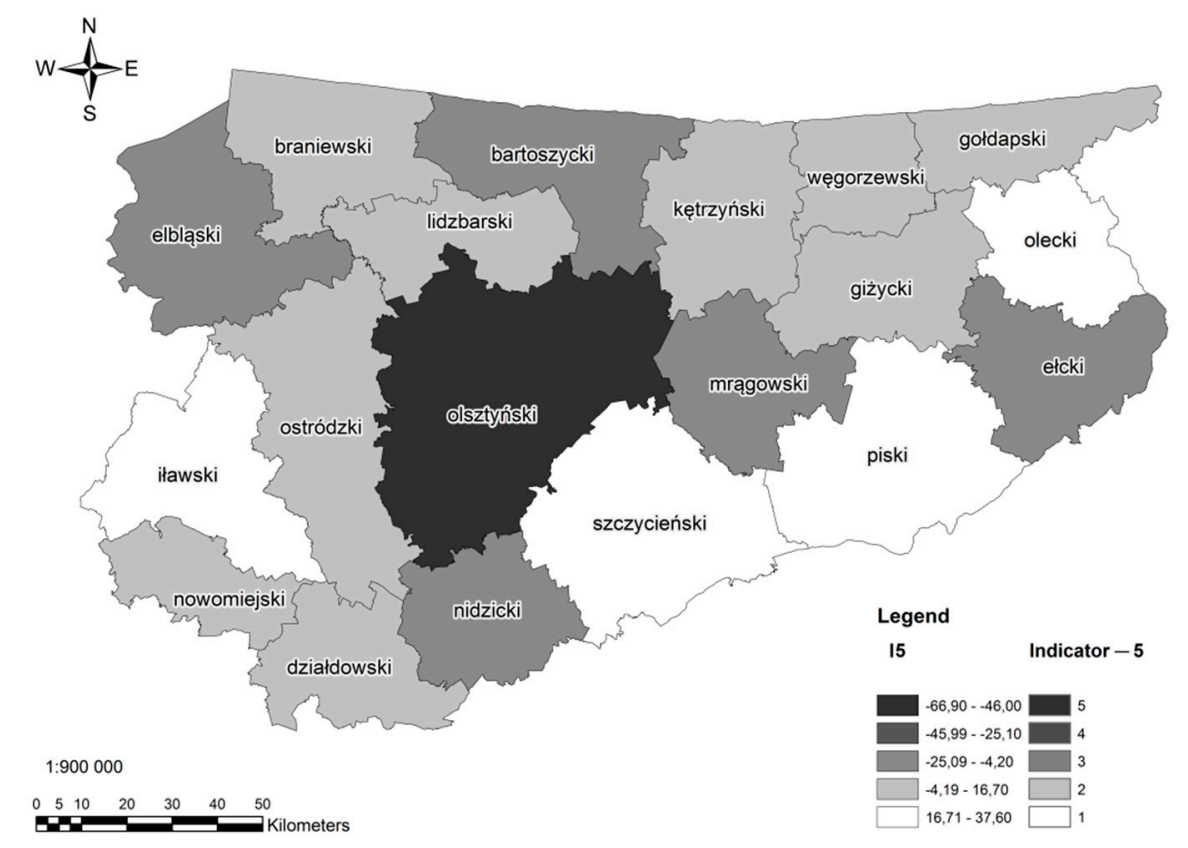

Figure 8. The increase or a decrease in the length of county roads with an improved surface. Source: Own study.

The last partial index-I6-refers to the proportion of the length of trunk roads whose repair was subsidised by the EU in the total length of trunk roads. It is close or equal to 0.00 in 14 counties; the highest index (0.65) was calculated for the county of Elblag in the western part of the province (Figure 9). Its value was also high in the county of Nidzica, where the $\mathrm{S} 7$ road was being constructed during the time period under study, which had its bearing on the calculation results. Similarly, the index has considerable values for the counties of Ostróda, Olsztyn, and Mragowo, where the largest EU-funded road investment projects were being carried out. Other counties located on the north and east, as well as three counties on the south-west received results in a first class (very close to zero) due to the lack of investment of this kind within the county.

It should be also emphasized that there is a strong positive correlation between some indicators. The results for indice I3-the length of roads under construction or under repair in a county $(\mathrm{km})$ are highly correlated with results I6-the proportion of the length of trunk roads whose repair was subsidised by the EU in the total length of trunk roads (correlation coefficient above 0.5). This indicates that some of the modernization processes initiated in the previous EU perspective were still ongoing or continued by other programmes from the 2014-2020 perspective.

Moreover, the index I3 is highly negatively correlated with I5. With the rise of construction works the length of county roads with an improved surface (i.e., better than a dirt road and worse than a bitumen road) decreases. We may assume that the road network in a certain county should be improved at different levels. 


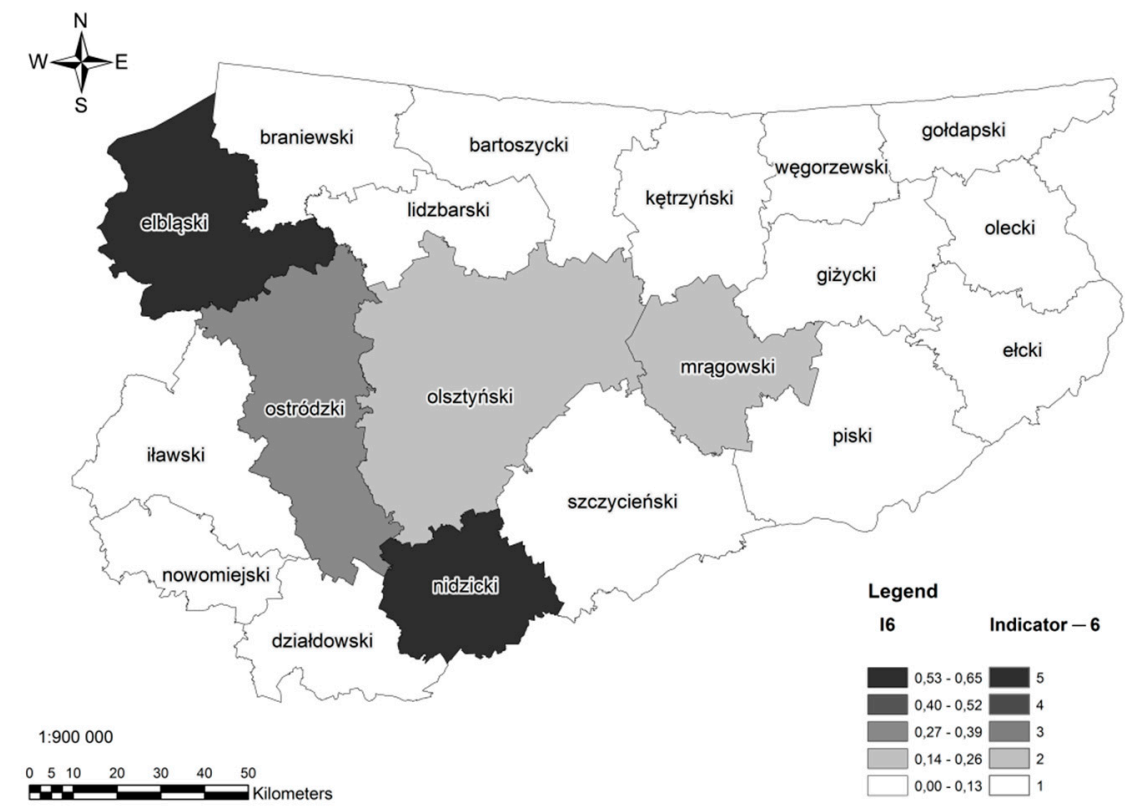

Figure 9. The proportion of the length of trunk roads whose repair was subsidised by the EU in the total length of trunk roads. Source: Own study.

In the next stage, the summary index was calculated, using the functions and tools of the GIS software, by introducing a unified classification. It helped to sum up all the indexes with the Raster Calculator tool, and, in effect, to present all the indexes on one sheet (after reclassification with the Reclassify tool, into another five intervals). Due to the fact that the data were not raster, each of the indicators was presented in a vector form and then using the Feature To Raster tool (with a cell size of 10), the vector data was converted into a raster data. It was necessary to perform the reclassification in order to unify the coefficients. Then, the Reclassify tool was used, thanks to which all six indicators were divided into new five classes (where five and black are the highest value, and one and white are the lowest). The unified classification allowed to sum up all the indicators with the Raster Calculator tool, and as a result to present all the indicators on one sheet (after re-classification with Reclassify on the same principles, into new five intervals). Each reclassified map presenting a partial index was added and one map with a summary index of the internal accessibility of counties was obtained.

Subsequently, the indexes were divided by the population density multiplied by 100 , in order to compare the final indexes of transport accessibility in the counties. The results showed that the county of Ostróda had the highest summary index (Figure 10). It is surprising that a relatively high accessibility was also calculated for the county of Węgorzewo, which stands out from the underinvested northern region. This may be attributed to the favourable spatial outlay (equal distance of the extreme points of the county to its capital-Węgorzewo, and its below-average area), as well as a favourable effect of the modernisation of regional roads. The level of accessibility decreases (the majority in class 1 ) as we move to the east and north. In addition, the county of Działdowo received a result in one class. It is also noteworthy that, even though results are diverse, we did not receive any results higher than 50 . It means that the level of accessibility should be improved in the whole region. 


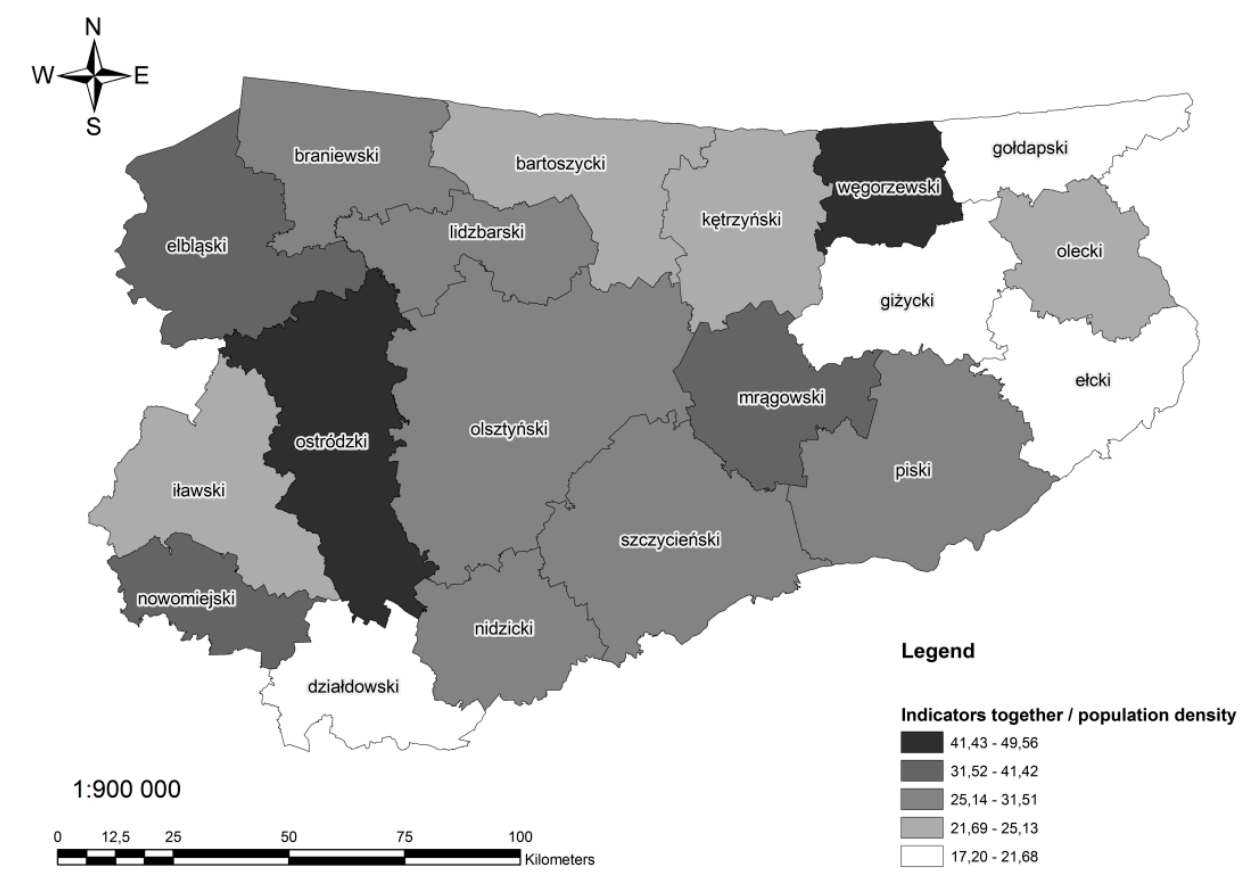

Figure 10. The summary index of the internal accessibility of counties. Source: Own study.

\section{Discussion, Summary and Conclusions}

This study focuses on road accessibility in areas where an insufficient number and scope of international and domestic investments can lead to an imbalance in the transport infrastructure. We have moved from the level of interregional connections to the local level, which involves trips that are made daily or several times a week. The transport infrastructure facilitates the personal contacts of rural and urban, which are still valuable and irreplaceable for rural residents [45]. The mobility is a facilitating factor in social exclusion, which exclusion has been seen to vary across services and facilities-often as a consequence of distance, or individual levels of this mobility [46]. Assuming that the county residents commute to work and travel to local shops or healthcare facilities, the internal accessibility of the county towns has been determined in view of the local inhabitants' basic needs and the trips made with medium and high frequency.

A set of indices relevant to the assumptions and goals of the present study have been adopted in view of the availability of data and the existing data processing options. The list of six partial indices was also created due to the specificity of the analysed area. The results for I 3 and I6 are positively correlated while I3 is negatively correlated with I5.

Accessibility in selected sub-regions in relation to the completed road investments has been determined and the highest results have been received for two counties lying on opposite sides of the region - the county of Weegorzewo and the county of Ostróda. In the county of Wegorzewo, the final result has been determined by one of the least travel times (I1) and the impact of EU subsidies on the modernisation and construction of regional roads for local use (I4). On the other hand, the result for the county of Ostróda are mostly caused by the investments on trunk roads subsidised also by EU funds. Among the county of Weegorzewo, the north-eastern part does not have a good accessibility level. These are counties situated far from the main roads, that may cause threats to regional cohesion resulting from the isolation of areas situated.

The authors are aware that in many online services (Google Maps, Targeo, etc.), the travel time is estimated with the use of algorithms in view of various factors, whereas the professional GIS software relies on, for example, a graph theory to find the best route based on the minimum spanning tree, solve the travelling salesman problem, or find the shortest path with the PERT and CPM tools. However, unlike the GIS software, online services do not support full comparisons within 
sub-regions or administrative units of a country based on the existing potential and the prospects for road development. Road networks constitute the basic components of the OpenStreetMap database. Road network representations are useful for many applications, but their "quality can vary between locations" [47].

The findings of this study revealed variations in the accessibility levels in regions. It should be noted that the following factors have contributed to the current state of affairs:

(1) Historical—before World War II, roads were designed to account for military needs and offer protection for columns of infantry and artillery through frequent changes in direction (road bends) and dense trees planted along the road shoulder;

(2) economic - the Region of Warmia and Mazury is not highly industrialised and it might be identified as a rural region. In the past, most incomes were derived from agriculture, whereas at present, tourism, especially the seasonal tourism, and natural resources (forests) play increasing roles in the regional economy;

(3) social—the majority of local residents are (from the long-term perspective) migrants from other parts of the country. Significant changes in migration and local employment patterns have been observed since the political transformations of the 1990s.

Despite the above, the applied methodology supported the description of areas that are underinvested and threatened with exclusion (in the northern part of the region). Some areas in the analysed region are situated in the proximity of the EU border, and their development is strongly affected by the political situation (cross-border trade, restrictions in the transport of goods or changes that facilitate cross-border exchange). Such areas were also identified in counties with satisfactory road accessibility and favourable development prospects, and the local authorities and businesses can rely on those advantages in promotional and marketing campaigns. Accessibility has a significant impact on local development by increasing the attractiveness of sub-regional markets [48]. However, the development of the road transport network in the Region of Warmia and Mazury is fraught with certain problems, even in areas where express roads are being developed. These include the time-consuming and conflict-generating process of land acquisition for investment projects, including by expropriation of rural land [33]. Moreover, the development of road infrastructure could affect the environment by fragmenting and altering animal habitats, as well as different kinds of pollutions. It must be emphasized that the Region of Warmia and Mazury is known for its priceless nature and the Great Masurian Lakes are among the World Wonders of Nature.

This study has a potential for development, and other determinants of accessibility, including the travel comfort, safety, and time (across seasons) can be analysed in the future to make our findings more comprehensive and universal. Other possible determinants include road width, the condition of road shoulders, number of road bends, terrain in the vicinity of a road, trees on the road shoulder, limitations on transit traffic or agricultural traffic, traffic separation at crossroads, annual and daily traffic fluctuations. These factors can be linked with detailed demographic analyses to determine the user profiles and needs. This paper was focused just on the road network properties, so the conclusions are valid from the point of view of private car owners primarily. However, they are important also for the youth without driving licenses or elderly people who have to use public bus transportation taking approximately the same routes. Yet, these kinds of analyses should take the transport means frequency into consideration and these kinds of travels duration, for example, by calculating the public transport efficiency index weighted by a certain coefficient [49].

This study analysed a selected area in Poland, but the adopted solutions can be extrapolated to address similar problems in other rural and peripheral regions in Europe and the world that lack sustainable policies for the development of transport networks. According to Janelle and Beuthe [50], "globalisation may favour the concentration of economic power and transport resources at major hubs, and the increasingly inequitable distribution of wealth and greater orientation towards regional 
specialisation in trade pose significant concerns". The lower accessibility of peripheral rural regions will compromise their economic development.

Peripheral regions in post-socialist countries appear to be particularly underinvested in terms of transport, including at the local and regional level. Despite the fact that political transformations in Central-Eastern Europe had occurred nearly three decades ago, most of these countries are still in need of regionally-oriented investments. The remoter rural areas, where income levels are generally low and economic opportunities limited are in most need of initiatives to increase accessibility [51]. Similar analyses could be conducted in the peripheral regions of countries along the eastern and southern borders of the EU, where the decision makers are likely to "provide inaccurate, vague or ambiguous assessments due to the incomplete information or inability of their processing in the given circumstances" [52]. The applied methodology, including the measures of the presented indices, can be applied to draft regional and sub-regional transport policies, plan transport services, and introduce an integrated planning approach to the transport development.

Author Contributions: Conceptualization, A.W., M.O., and R.Ź.; Methodology, A.W. and M.O.; Software, A.W. and M.O.; Validation, A.W., M.O., and R.Ź.; Formal analysis, A.W. and M.O.; Investigation, A.W. and M.O.; Data curation, M.O.; Writing—original draft preparation, A.W.; Writing—review and editing, A.W.; Visualization, A.W. and M.O.; Supervision, R.Ź.; Project administration, R.Ź.; Authorship must be limited to those who have contributed substantially to the work reported.

Funding: This research received no external funding.

Acknowledgments: We thank General Directorate for National Roads and Motorways (GDfNRM), the Road Board of the province of Warmia and Mazury (WMRB) for giving access to necessary materials.

Conflicts of Interest: The authors declare no conflict of interest. The funders had no role in the design of the study; in the collection, analyses, or interpretation of data; in the writing of the manuscript, or in the decision to publish the results.

\section{References}

1. Antrop, M. Landscape change and the urbanization process in Europe. Landsc. Urban Plan. 2004, 67, 9-26. [CrossRef]

2. WCED, UN. Our Common Future; World Commission on Environment and Development; Oxford University Press: Oxford, UK, 1987.

3. Richardson, B.C. Sustainable transport: Analysis frameworks. J. Transp. Geogr. 2005, 13, 29-39. [CrossRef]

4. Owen, W. Special problems facing underdeveloped countries. Transportation and economic development. Am. Econ. Rev. 1959, 49, 179-187.

5. Ng, C.P.; Law, T.H.; Wong, S.V.; Kulanthayan, S. Relative improvements in road mobility as compared to improvements in road accessibility and economic growth: A cross-country analysis. Transp. Policy 2017, 60, 24-33. [CrossRef]

6. Van de Walle, D. Choosing rural road investments to help reduce poverty. World Dev. 2002, 30, 575-589. [CrossRef]

7. Halden, D. Accessibility analysis concepts and their application to transport policy, programme and project evaluation'. In Transport Projects Programmes and Policies: Evaluation Needs and Capabilities; Pearman, A., Mackie, P., Nellthorp, J., Eds.; Ashgate: Aldershot, UK, 2003; pp. 227-242.

8. Thorsen, H.S.; Thorsen, I. Effects of transportation barriers on geographic asymmetries in labour markets. Res. Transp. Econ. 2017, 63, 27-37. [CrossRef]

9. Givoni, M. Assessing core-periphery relation through travel patterns-The case of Israel. Res. Transp. Econ. 2017, 63, 73-85. [CrossRef]

10. Ribeiro, A.; Antunes, A.P.; Páez, A. Road accessibility and cohesion in lagging regions: Empirical evidence from Portugal based on spatial econometric models'. J. Transp. Geogr. 2010, 18, 125-132. [CrossRef]

11. Soliño, A.S.; Galera, A.L.L.; Colín, F.C. Valuation of the option of early reversion in road concessions. Eur. J. Transp. Infrastruct. Res. 2018, 18, 239-249.

12. Linneker, B.J.; Spence, N.A. An accessibility analysis of the impact of the M25 London orbital motorway on Britain. Reg. Stud. 1992, 26, 31-47. [CrossRef] 
13. Taylor, M.A.; Sekhar, S.V.; D’Este, G.M. Application of accessibility based methods for vulnerability analysis of strategic road networks. Netw. Spat. Econ. 2006, 6, 267-291. [CrossRef]

14. López, E.; Gutiérrez, J.; Gómez, G. Measuring regional cohesion effects of large-scale transport infrastructure investments: An accessibility approach. Eur. Plan. Stud. 2008, 16, 277-301. [CrossRef]

15. Feltynowski, M. Dostępność komunikacyjna jako element rozwoju gmin wiejskich łódzkiego obszaru metropolitalnego. (The communications availability as the element of the development of rural municipalities of Łódź metropolitan area). Infrastruktura i Ekologia Terenów Wiejskich 2009, 39, 197-207.

16. Taylor, M.A.; Susilawati. Remoteness and accessibility in the vulnerability analysis of regional road networks. Transp. Res. Part A Policy Pract. 2012, 46, 761-771. [CrossRef]

17. Busscher, T.; Tillema, T.; Arts, J. In search of sustainable road infrastructure planning: How can we build on historical policy shifts? Transp. Policy 2015, 42, 42-51. [CrossRef]

18. Li, T.; Yang, W.; Zhang, H.; Cao, X. Evaluating the impact of transport investment on the efficiency of regional integrated transport systems in China. Transp. Policy 2016, 45, 66-76. [CrossRef]

19. Salon, D. Heterogeneity in the relationship between the built environment and driving: Focus on neighborhood type and travel purpose. Res. Transp. Econ. 2015, 52, 34-45. [CrossRef]

20. Olsson, J. Improved road accessibility and indirect development effects: Evidence from rural Philippines. J. Transp. Geogr. 2009, 17, 476-483. [CrossRef]

21. Geurs, K.T.; Van Wee, B. Accessibility evaluation of land-use and transport strategies: Review and research directions. J. Transp. Geogr. 2004, 12, 127-140. [CrossRef]

22. Dąbrowska-Loranc, M.; Wojsz, T. (Eds.) 'Prędkość Pojazdów w Polsce w 2014 r.' ('Vehicle Velocity in Poland in 2014'); Ministerstwo Infrastruktury i Rozwoju: Warszaw, Poland, 2014. Available online: www.krbrd.gov.pl (accessed on 27 August 2019).

23. Indriasari, V.; Dean, D. The Minimum Step Linkage Algorithm and Cumulative Cost Model for Time-Dependent Shortest Paths'. Trans. GIS 2016, 20, 962-975. [CrossRef]

24. Wiśniewski, S. Zmiany dostępności miast województwa łódzkiego w transporcie indywidualnym w latach 2013-2015 (Changes in the accessibility to private transport of towns in Poland's Łódź voivodship in the years 2013-2015). Prz. Geogr. 2015, 87, 321-341. [CrossRef]

25. Vickerman, R. Beyond cost-benefit analysis; the search for a comprehensive evaluation of transport investment'. Res. Transp. Econ. 2017, 63, 5-12. [CrossRef]

26. Shay, E.; Combs, T.S.; Findley, D.; Kolosna, C.; Madeley, M.; Salvesen, D. Identifying transportation disadvantage: Mixed-methods analysis combining GIS mapping with qualitative data. Transp. Policy 2016, 48, 129-138. [CrossRef]

27. Forslund, U.M.; Johansson, B. Assessing road investments: Accessibility changes, cost benefit and production effects. Ann. Reg. Sci. 1995, 29, 155-174. [CrossRef]

28. Hawas, Y.E.; Hassan, M.N.; Abulibdeh, A. A multi-criteria approach of assessing public transport accessibility at a strategic level. J. Transp. Geogr. 2016, 57, 19-34. [CrossRef]

29. Järv, O.; Tenkanen, H.; Salonen, M.; Ahas, R.; Toivonen, T. Dynamic cities: Location-based accessibility modelling as a function of time. Appl. Geogr. 2018, 95, 101-110. [CrossRef]

30. 'Raport o Stanie Technicznym Nawierzchni Sieci Dróg Krajowych na Koniec 2015 Roku', 'Raport o Stanie Technicznym Nawierzchni Sieci Dróg Krajowych na Koniec 2004 Roku’. Available online: https://www. gddkia.gov.pl/pl/2990/Raporty (accessed on 15 May 2017).

31. Chen, Z.; Liu, Y.; Feng, W.; Li, Y.; Li, L. Study on spatial tropism distribution of rural settlements in the Loess Hilly and Gully Region based on natural factors and traffic accessibility. J. Rural Stud. 2019. [CrossRef]

32. Wyniki badań bieżących. Available online: http://demografia.stat.gov.pl/bazademografia/Tables.aspx (accessed on 31 January 2018).

33. Walacik, M. Opracowanie Zasad Ustalania Wysokości Słusznego Odszkodowania za Nieruchomości Przejęte na Cele Publiczne ('Development of the Principles for Determining the Amount of Fair Compensation for the Property Taken for Public Purposes') Rozprawa Doktorska, Olsztyn. 2011. Available online: http://www. ndb.pl/files/wydawnictwo/Seria_Nieruchomosci-Monografia_2014-1.pdf (accessed on 15 February 2017).

34. Meijers, E.; van der Wouw, D. Struggles and strategies of rural regions in the age of the 'urban triumph'. J. Rural Stud. 2019, 66, 21-29. [CrossRef]

35. Drogi wojewódzkie w opłakanym stanie. Sprawdź, gdzie jest najgorzej i które czekają na remont. Available online: https://ro.com.pl/328049-2/01328049 (accessed on 10 February 2018). 
36. Black, J.; Conroy, M. Accessibility measures and the social evaluation of urban structure. Environ. Plan. A 1977, 9, 1013-1031. [CrossRef]

37. Hansen, W.G. How accessibility shapes land use. J. Am. Inst. Plan. 1959, 25, 73-76. [CrossRef]

38. Luo, W.; Wang, F. Measures of spatial accessibility to health care in a GIS environment: Synthesis and a case study in the Chicago region. Environ. Plan. B Plan. Des. 2003, 30, 865-884. [CrossRef]

39. Pearce, J.; Witten, K.; Bartie, P. Neighbourhoods and health: A GIS approach to measuring community resource accessibility. J. Epidemiol. Community Health 2006, 60, 389-395. [CrossRef] [PubMed]

40. Gutierrez, J.; Gonzalez, R.; Gomez, G. The European high-speed train network: Predicted effects on accessibility patterns. J. Transp. Geogr. 1996, 4, 227-238. [CrossRef]

41. Cantos-Sánchez, P.; Moner-Colonques, R.; Sempere-Monerris, J.J.; Álvarez-SanJaime, Ó. Viability of new road infrastructure with heterogeneous users. Transp. Res. Part A Policy Pract. 2011, 45, 435-450. [CrossRef]

42. De Oliveira, E.L.; da Silva Portugal, L.; Junior, W.P. Indicators of reliability and vulnerability: Similarities and differences in ranking links of a complex road system. Transp. Res. Part A Policy Pract. 2016, 88, 195-208. [CrossRef]

43. Data classification methods-ArcGIS Pro|ArcGIS Desktop. Available online: http://pro.arcgis.com/en/proapp/help/mapping/symbols-and-styles/data-classification-methods.htm (accessed on 15 May 2017).

44. Metody klasyfikacji-ArcGIS Maps for Office. Available online: https://doc.arcgis.com/pl/maps-for-office/ design-and-use/about-arcgis-maps-for-office.htm (accessed on 15 May 2017).

45. Escalona-Orcao, A.I.; Sáez-Pérez, L.A.; García, B.S.V. Location conditions for the clustering of creative activities in extra-metropolitan areas: Analysis and evidence from Spain. Appl. Geogr. 2018, 91, 1-9. [CrossRef]

46. Shergold, I.; Parkhurst, G. Transport-related social exclusion amongst older people in rural Southwest England and Wales. J. Rural Stud. 2012, 28, 412-421. [CrossRef]

47. Brovelli, M.A.; Minghini, M.; Molinari, M.; Mooney, P. Towards an automated comparison of OpenStreetMap with authoritative road datasets'. Trans. GIS 2017, 21, 191-206. [CrossRef]

48. Wolny, A. Accessibility of Real Estate by Transportation as a Determinant of the Development of Suburban Real Estate Markets-Case Study'. Real Estate Manag. Valuat. 2016, 24, 5-18. [CrossRef]

49. Janelle, D.G.; Beuthe, M. Globalization and research issues in transportation. J. Transp. Geogr. 1997, 5, 199-206. [CrossRef]

50. Wolny, A. Are suburban commuters confined to private transport? A case study of a medium-sized functional urban area (FUA) in Poland. Cities 2019, 92, 82-96. [CrossRef]

51. Gray, D.; Farrington, J.; Shaw, J.; Martin, S.; Roberts, D. Car dependence in rural Scotland: Transport policy, devolution and the impact of the fuel duty escalator. J. Rural Stud. 2001, 17, 113-125. [CrossRef]

52. Tadić, S.; Krstić, M.; Roso, V.; Brnjac, N. Planning an Intermodal Terminal for the Sustainable Transport Networks. Sustainability 2019, 11, 4102. [CrossRef] 